\title{
Investigation of Key Problems and Future Development of China's Endowment
}

\author{
$\operatorname{Lan} \mathrm{Ma}^{1,2}$ \\ ${ }^{1}$ Jiangsu Provincial Academy of Social Sciences, Nanjing, P. R. China \\ ${ }^{2}$ School of Social and Behavior Science, Nanjing University, Nanjing, P. R. China
}

Email address :

malan_jsass@126.com

\section{To cite this article:}

Lan Ma. Investigation of Key Problems and Future Development of China's Endowment. Humanities and Social Sciences. Vol. 6, No. 3, 2018, pp. 97-102. doi: 10.11648/j.hss.20180603.12

Received: May 24, 2018; Accepted: June 19, 2018; Published: July 11, 2018

\begin{abstract}
The basic endowment insurance system for enterprise employees has already covered migrant workers in China. However, a number of migrant workers have withdrawn from insurance system in economically developed regions in recent years. And the number is on the rise. The root cause for it lies in the institutional barrier of trans-regional migration. Besides, it also closely linked to the internal contradictoriness in the endowment insurance system. This paper aims at discussing how to break the trans-regional migration obstacles of endowment insurance system and promote the current pooling account from provincial level to national level. Based on the analysis on China's basic endowment insurance system, four main problems has been found. They are county-based system and low level of pension pooling, trade-off in local governments caused by fiscal backstop, restrictions from the existing fiscal system, and implement of policies relies heavily on execution of basic-level governments. In order to solve these problems of existing endowment insurance system, establishing an integrated endowment insurance system which covers the whole Chinese citizens is further proposed. In addition, confronted with the current fact that we have a big gap of social security treatment between urban and rural areas, among different regions and among various groups, the feasible solution is to complete transformation from differential universal-type social welfare system to fair universal-type social welfare system. To promote the current pooling account from provincial level to national level, it needs to be carried forward systematically and stage by stage.
\end{abstract}

Keywords: Endowment Insurance System, National Pooling, Local Governments' Interests, Tax Federalism, Universal-Type Social Security System

\section{Introduction}

Social insurance is one of the most important and fundamental parts in social security system [1-4]. And endowment insurance plays a significant role in social insurance system because of its wide-ranging and profound impact $[5,6]$. Many researchers have paid more attention to the operation of the endowment insurance systems all over the world [7-10]. However, it should be noted that each country has its own characteristics. According to Statistical Communiqué of the People's Republic of China on the 2014 Labor and Social Security Development published jointly by Ministry of Human Resources and Social Security of the People's Republic of China and the National Statistical Offices of China, the total revenue of social security fund amounted to 3982.8 billion yuan in 2014 , more than two thirds of which comes from endowment insurance fund whose total revenue is 2762 billion yuan [11]. The total revenue is very steady these years. Not surprisingly, the endowment insurance carries a big weight in the whole social security system of China.

Endowment insurance which is on the top list of China's insurance system has experienced transformation over a decade under the progressive reform guiding ideology of the authorities and has established a basic framework for social endowment insurance system for urban employees successfully. cIn a comparison with other parts of China's insurance system it is more advanced. However, the way how endowment insurance performs is still problematic and there appears to be a lot of contradictions inside because of China's urban-rural dual structure, unbalanced regional economic 
development between eastern and western areas, an enormous rural population, household registration system and so on. Under this background, on one hand, the rate of insurance coverage of migrant worker is pretty low, and it was only $16.7 \%$ in 2014 [12]. On the other hand, the surrender rate is very high. The average level of whole country is $40 \%$ [13], and this percentage rises to $80 \%$ in some cities of Guangdong where numerous migrant workers live and work [14].

Why don't the migrant workers participate endowment insurance and even if they do, why would many of them withdrawn from it in several years later? The main reason is the difficulty of trans-regional migration for migrant workers. That is the biggest institutional barrier for the endowment insurance. Under this background, this paper wants to discuss the cause of the trans-regional migration obstacles and provide a solution to solve this problem. In this paper, the problems of China's basic endowment insurance system has been analyzed. And the results indicate that it is necessary to establish an integrated endowment insurance system which covers the whole Chinese citizens. This system should be carried forward systematically and stage by stage, because there is a big gap of social security treatment between different regions and various groups. This approach gives attention to the requirement of both operability and compatibility, and has great significance for the development of endowment insurance system.

\section{Analysis on the Essential Problems of China's Endowment Insurance}

\subsection{County-Based System and Low Level of Pension Pooling}

When China's endowment insurance system was established, it was based on counties and districts to balance its development, which means employers and employees from the same county have unified endowment insurance base pay, payment ratio and payment items, and unified standard for fund management. Although the policy orientation of government is to unify basic endowment insurance at the provincial level and 28 provinces claim that they have reached the goal, by now there are only 7 provinces (including Beijing, Shanghai, Tianjin, Chongqing and so on) which have accomplished the goal and the rest of them still stay at the county level.

The reason why the basic endowment insurance of China is carried out at such low administrative level lies in the original path choice of the system design. In the early 1990s, the development path of the pension pooling level erupted an emotive discussion. The central government expects overall planning in the whole china and to realize the integration strategy in endowment insurance. On the contrary, the local governments desire to be given greater autonomy. And local officials believe that more marketization a region becomes, more autonomy it should have. As local governments' interests have been deepen, it makes it very difficult to transform to a higher pooling level. In the game playing the local governments took an advantage because the central government didn't have enough money for the national pooling and didn't want to burden the whole responsibility as there weren't a clear number of the historical debts. One typical example is that the money in individual account paid by younger people is used to support aged ones. The "empty account" of individual endowment insurance account in the whole China has become a reality and the shortfall has already been over hundreds of millions yuan. Unfortunately, it is still on the rise. The relationship between province and city, city and county are in the same way. So, it is imperative to conduct a top-down development path. In recent tax-sharing system, to raise pension pooling level from down to top will make the inter-government fiscal relationship very complicated because of so many uncertainties between different hierarchies. As a consequence, it isn't feasible to raise the pooling level, which means it is easier said than done. The existing county-based pooling system is small-scale and low-level. It has weak anti-risk capabilities and the insurance files can't be transferred easily from one place to another, which is the reason why law of large numbers and mutual-help function of insurance can't be full played. Governments at all levels work totally independently, which makes it very difficult for social insurance to continue to work effectively in another different place. The large-scale collective withdrawing from endowment insurance among migrant workers is the result of low-level pooling and inter-provincial flow restriction [15].

\subsection{The Trade-off in Local Governments Caused by Fiscal Backstop}

Pension insurance fund in China conducts independent accounting. And the job of local government is to make sure that the pension insurance fund makes its both ends meet and the pension of retirees can be paid on time and in full, if not, the local finance bureau backstops. Contemporarily, most of areas in China are county-pooling combined with province-level adjustment fund. To put it another way, endowment insurance of China is based on county finance mainly and the provincial finance is just for emergency situation, which is the reason why the county finance take the responsibility of balance of payments. There turns out to be a shortfall in pension fund in most regions of China and local governments are facing with great pressure to provide enough pension to retirees, which is a barrier to insurance transfer because local governments believe that insurance transfer is harmful to the balance of payments. All these have caused benefits division and circumvention of liability.

Compared with urban employees, migrant workers have a high mobility and they tend to pay their premium in relatively more advanced areas and when they retire and need to be supported by insurance they go home where is less developed economically. According to the existing system it is admitted to transfer the total premium paid before your retirement but not the part paid by local governments' finance. However, when it comes to benefits of retirees, it is closely related to how long you have paid, which suggests that insurance transfer will damage local interests. To be more specific, for 
emigration places transferring money out of social pooling account means a reduction of pooling fund. For immigration places, without pooling fund transferring in they have to capitalize on local pooling fund to support theses to-be-retirees while emigration places have more pooling fund accumulation. The insurance transfer is risk-taking and money-losing for economic less-developed regions. Contrarily, it means less economic burden for developed regions [16]. As a result, although the central government has introduced preferential transfer and continuation policies, the majority of immigration places set institutional barriers against insurance transfer.

\subsection{Restrictions from the Existing Fiscal System}

In order to improve the macro-control ability of central government and to handle well with the relationship between central and local finance allocation, China began a taxation reform named as tax federalism in 1994 that central and local governments work independently with respect to items of taxation, taxation right and taxation management. This is a system of dividing revenue and expenditure between the central and local governments. Governments at each administrative level are just responsible for their own budget. From the perspective of social security construction, the existing fiscal system has three major drawbacks as follows.

Firstly, with financial strains caused by the existing fiscal system, the local governments have no extra money to invest in social security. After taxation reform, as central fiscal revenues better, the ability of central transfer payment has been improved effectively. For local governments, that is a totally different picture. Their financial power isn't equal to their administrative power. Governments at lower level have to take part of their tax revenue to the higher level, which greatly weakens the financial power of county-level governments and causes financial strains in grass-roots governments. Meanwhile the local governments have more duties and responsibilities especially heavy expenditure responsibilities that their expense is large and grows fast. Besides, the administrative power of basic-level governments is rigid. The direct influence is that there is a big shortfall of public products supplied by basic-level governments and the financial situation of basic-level governments is the weakest part of the whole finance system. Grass-roots governments are in a financial swamp and even don't have enough money to pay all employees, which means they don't have extra money to invest in social security [17].

Secondly, because of the historical restrictions social security wasn't listed on the fiscal expenditure project and its expenditure was underestimated when tax federalism reform was started at first. Under this circumstance, structural difficulties and institutional barriers of social security come into being. Even later as social security expenditure increases gradually, social security responsibilities aren't divided reasonably between central and local governments. Even if we have Organic Law of the Central and Local People's Governments of the PRC in China, the criteria of segregation of duties aren't specific and clear and the boundaries of finance and administrative power of governments at all level aren't clear-cut, which causes a lot of randomness in the practice. None of governments invest money in social security actively and without any reluctance as a result of unclear powers and responsibilities. The fact is that the finance of local governments depends on the central government's [18].

Thirdly, the public finance has become officials' finance because fiscal revenues can just cover the civil servants' salaries and office expense and have no remaining money to improve people's livelihood. The taxes are taken from citizens but not used to improve citizens' life quality. Since the reform and opening up policy in 1978, Chinese fiscal revenues increase by 20 percent or 30 percent every year, only $12 \%$ of which are used to support social security. However, over $30 \%$ of American fiscal revenues are invested in social security. And the number in Canada is 39\% with western and northern Europe both over 45\% [19]. Meanwhile the administrative costs of China rank first in the world.

Because of these shortcomings as above, the existing fiscal system poses a structurally and institutionally bad influence on China's social security system construction as follows.

On one hand, the tax federalism reform just makes it clear that the central and local governments have different financial administrative power under the historical condition at that time. But as the financial and administrative power in one province, the top-down power division isn't clear-cut [18]. When it comes to endowment insurance transfer, separated and independent financial system makes insurance transfer damage local interests. Insurance transferring out means a reduction of responsibility and transferring in means to be burdened with more old-age people. The basic national situation of China is obvious and apparent unbalanced regional economic development and this situation is also reflected in one province. Take economically developed provinces such as Guangdong province and Jiangsu province for example. Yuebei district are less developed than Yuenan district. And Jiangsu province is the same, Subei district are less developed than Sunan district. Unbalanced economically development causes different level of social security in whole China. Even under the national relevant regulations and policies all local governments prefer insurance transferring out to transferring in. In particular, urban areas can't accept individual accounts from rural areas and developed areas don't want insurance transfer from underdeveloped areas.

On the other hand, as tax federalism reform doesn't handle the problem concerning social security responsibility division. When confronted with social security investments, the local governments always have "money issues" and find it hard to have enough resources. If the central government holds the whole responsibility, the financial burden on it will be too heavy. If the central government cooperates with the local governments, the ratio of contributions isn't clear institutionally. And if the local governments' finance covers all social security expenses, some underdeveloped prefectural-level cities and counties will have finance troubles. The final resolution in most areas is local finance combined with inter-government transfer payment that the 
central government transfers payments to the central and western regions and provincial finance transfers payments to poor counties. But the way how transfer payment works lacks of reasonable foundations and efficiency and gives rise to further social security inequality. For many years China's social security construction with these institutional contradictions has struggled ahead which inevitably causing increased decision-making costs, financial difficulties and so on [18]. Fiscal system is a man-made factor and causes inter-government game-playing.

\subsection{The Implement of Policies Relies Heavily on Execution of Basic-Level Governments}

The governmental hierarchy in China is characterized by five and half different government levels, which is unique in the world. Compared with any great powers in the whole global, this administrative feature gives rise to complex relationships among governments at different level on matter in a country or in a province, which hinders policy execution and institution unification. Local governments always evade the duties and responsibilities assigned by central government. The responsibility boundaries of governments at different level in endowment insurance system for migrant workers aren't clear and how the capital management and control right was allocated isn't regulated by provisions. As a result, whether the central policies can be carried through or not depends heavily on county-level governments' execution which is closely linked with how much the local governments can benefit from.

Undeniably, local governments are responsible for social security fund's management and functioning, which means the social security departments of local governments are not only supervisors and asset managers but also clients and investors, which is susceptible to appropriation and corruption when restriction and close supervision are neglected.

Four major institutional barriers to endowment insurance trans-regional transfer are low-level pooling, separate fiscal system, local interests conflict and unsound cohesive mechanism which directly causes a reduction of insurance participation of floating population. Migrant workers which are the main body of the floating population can't accomplish the shift-and-renewal of endowment insurance because of transformation of identity and region.

\section{Discussion on the Establishment of an Incorporate and Universal-Type Endowment Insurance System in China}

The main functions of social security is to serve as the social safe net, to realize social justice to the utmost through national income redistribution [20], to remove social uncertainty in the operation of competition mechanism and to eliminate social instability [21]. The ultimate goal of China's social security is to establish an incorporate and universal-type endowment insurance system which is available to all Chinese citizens. However, in view of the fact that there is a big gap of social security treatment between urban areas and rural areas, among different regions and among different groups, the feasible path is to narrow the gap gradually and complete a transformation from discriminating social security treatment to fair treatment which is a big step to promote social fairness and national well-being. Only national co-ordination is achieved can a universal-type social security system be established. One of the big steps to strengthen and perfect the social security system is to build a national co-ordinate universal basic pension system. However, it still has a long way to go to achieve a national co-ordination [22].

In the existing informatization condition, the technical obstacles in the endowment insurance policy design caused by regional economic difference and great wage disparity can be conquered with public management abilities. Great wage disparity enjoys its popularity in the world. But many countries have established a relatively mature social security system under which insurance can be transferred and continued freely with the aid of information technology, network management platform and endowment insurance design in keeping with high employee mobility rates. There is no unsolvable technical problem if China wants to be one of them, the top priority is that central government should cooperate and coordinate with local governments and a new institutional arrangement for capital pooling should be made to balance regional differences. It may take 30 or 50 years for China to complete this ultimate goal because it is highly associated with the schedule of regional development coordination and regional differences removal [23].

To make the long-term goal of national pooling come true, the plan needs to be carried forward systematically and stage by stage.

Firstly, implement a national budget. Take regional differences into account, evade the most difficult parts of the system and break division. The whole train of thought is that employees pay their premium at their working places and all the details related to premium will be recorded in divided periods and when they retired they can get their pension at their living places. To be more specific, under the divided endowment insurance system it is necessary to establish social security payments accounting centers at central and provincial governments which aim at helping retirees and mobile workers get their deserved pension at their living places. According to labor service records and corresponding provincial population base the provincial centers keep separate accounts. Then, central accounting center takes a lead and implements fund flow among various provinces and cities. It successfully evades issues concerning individual account and pooling fund transfer and also gives full consideration to how to work with the existing region-divided endowment insurance system. This innovation has enlightening significances [24].

Secondly, improve and perfect legislation. Market economy needs a legal environment, so does social insurance. The basic principle is to establish related laws first. When many 
industrialized countries and developing countries begin to establish and reform the endowment insurance system, they base the establishment and transformation on laws and regulations made by legislature combined with implementing rules enacted by administrative departments. China lacks of endowment insurance laws and regulations and the transformation is based on policy documents issued by administrative agencies. It won't be helpful to institutionalization and stability of new endowment insurance system. Without endowment insurance legislation means lack of legal authority and legal sanction, which will make related duties and responsibilities burdened by nation, companies and individuals unclear. It is imperative that it should observed Social Insurance Law, which will make endowment insurance go further on the road to legalization and standardization [25].

Meanwhile different legal departments need to cooperate and coordinate with each other. For example, when social security tax replace premium is used, it should be collected by tax department and compatible with tax law. When social security funds are changed into security rights which come first compared with general creditor's rights, it should take property law which is being made right now into account. And when employers' endowment insurance payment obligation is put into contract, it needs to consider Contract Law fully.

Thirdly, make social security rights and liabilities clear and fiscal responsibilities of government at all levels need to be distributed scientifically and reasonably [26]. The current problem which needs to be solved immediately is which level of financial budget can be used to cover a county or a city's endowment insurance fund shortfalls. According to Decision of the Central Committee of the Communist Party of China on Some Issues Concerning the Improvement of the Socialist Market Economy issued by the Third Session of the $16^{\text {th }}$ Central Committee of the Party, it is necessary to figure out gradually the central and local governments' roles and responsibilities in social security in accordance with their division of economic and social affairs management in liabilities. There are three rules to comply with. The first is clarity. In the long-term planning of social security the obligations for payment of governments at all levels in each project need to be clearly outlined. The second rule is to be scientific. Considering the fact that central and provincial governments are richer than basic-level governments in terms of finance, it is supposed to evaluate the social security responsibilities of governments at all levels and are expected to transfer some projects which local governments can't be responsible for to central and provincial governments. The third one is unification of financial and administrative powers. No matter how we divide the social security responsibilities it is essential to evaluate the original fiscal revenue distribution. Therefore, it should be necessary to adjust the distribution ratio of fiscal incomes in line with their financial responsibilities [18].

When solving social endowment insurance transfer for migrant workers and non-working urban residents, it should be necessary to see the whole picture and be fair, square and realistic. And our policy arrangement should be systematic and it should be a low-level, widely-covered, flexible and well-adapted policy. As to places where national treatment policy has been implemented and migrant workers have been included into urban insurance system, it should be not expected to return to migrant workers' endowment insurances. Besides, setting up pension insurance for migrant workers alone is still open to discussion. Migrant workers who have permanent jobs in urban areas should be covered by basic endowment insurance system for the urban working group and their insurance transfer should also adhere to the standard of urban insurance transfer. If the overall planning and national pooling of endowment insurance is accomplished, migrant workers can go anywhere they want with their social security number which has the information of their payment records. I believe that migrant workers will choose to continue their insurance rationally rather than withdrawing it under the new insurance system.

\section{Conclusion}

In this paper, the essential problems of China's Endowment Insurance have been analyzed. We find these four most important factors, which are County-based system and low level of pension pooling, the trade-off in local governments caused by fiscal backstop, restrictions from the existing fiscal system, and the execution ability of basic-level governments, could lead to the low rate of insurance coverage and high surrender rate of migrant workers. Based on the further analysis on how these four factors affect China's basic endowment insurance system, we propose that the ultimate goal of China's social security is to establish an incorporate and universal-type endowment insurance system which is available to all Chinese citizens. And national budget, legal environment, clear social security rights and liabilities are indispensable to the universal-type endowment insurance system. However, the ultimate goal needs to be achieved systematically and stage by stage because of the big gap of social security treatment between different areas and different groups. And the feasible path is to narrow the gap gradually and complete a transformation from discriminating social security treatment to fair treatment.

\section{Acknowledgements}

This work was supported by the National Social Science Foundation of China under Grant 13CSH110 and Jiangsu Provincial normal university graduate research innovation project of China CXLX13_010.

\section{References}

[1] Hyoung, L. J. (2017) A study on the New-pattern Rural Social Endowment Insurance System in China. Korean Journal of Political Science. 25 (4). 165-186.

[2] Chen, R. Li, N. X. and Liu, X. (2018) Study on the Equity of Medical Services Utilization for Elderly Enrolled in Different Basic Social Medical Insurance Systems in an Underdeveloped City of Southwest China. International Journal for Equity in Health. 17. 54. 
[3] Wu, Y. Y. and Yuan, Y. (2016) Research on Integration Conception of Urban and Rural Endowment Insurance System. AEBMR-Advances in Economics Business and Management Research. 9. 25-27.

[4] Liu, H. J. and Zhu, Z. G. (2016) The Exploration of the New Type of Rural Social Endowment Insurance System in China. 54. 360-365.

[5] Tan, S. Y. Wu, X. and Yang, W. (2018) Impacts of the Type of Social Health Insurance on Health Service Utilisation and Expenditures: Implications for a Unified System in China. Health economics, policy, and law. 1-19.

[6] Xie, Y. S. (2017). Present Situation Problems and Countermeasures of Rural Endowment Insurance System in China. Advances in Social Science Education and Humanities Research. 101. 736-739.

[7] Kitao, S. (2015). Pension Reform and Individual Retirement Accounts in Japan. Journal of the Japanese and International Economies. 38. 111-126.

[8] Vukorepa, I. (2015). Lost between Sustainability and Adequacy: Critical Analysis of the Croatian Pension System's Parametric Reform. Revijaza Socijalnu Politiku. 22 (3). 279-308.

[9] Wang, L. J. (2015). Nonlinear Differential Equations and Feedback Control Design for the Urban-Rural Resident Pension Insurance in China. International Journal of Bifurcation and Chaos. 25 (14). 1540029-1-1540029-8. http://dx.doi.org/10.1142/S0218127415400295.

[10] Wolff, E. N. (2015). US Pensions in the 2000s: The Lost Decade. Review of Income and Wealth. 61 (4). 599-629.

[11] Ministry of Human Resources and Social Security of the People's Republic of China. (2015). Statistical Communiqué of the People's Republic of China on the 2014 Labor and Social Security Development, [Online] Available:http://www. mohrss.gov.cn/SYrlzyhshbzb/zwgk/szrs/tjgb/201506/t201506 29_212661.html (June 29, 2015).

[12] Yuan, M. Q., Li, B. B. (2015). The Rate of Insurance Coverage of Migrant Worker is Less than 20\%. [Online] Available:chttp://society.people.com.cn/n/2015/0804/c1008-2 7404983.html (August 4, 2015).

[13] Lai, J. Q., Hu, Z. H. (2006).The Underlying Apprehension of High Surrender Rate of Migrant Workers. [Online] Available: http://www.xinhuanet.com/chinanews/2006-02/14/content_62 38547.html (February 14, 2006).

[14] Wu, B. (2008). What Leads to the High Surrender Rate of
Migrant Workers. [Online] Available: http://cpc.people. com.cn/GB/64093/82429/83083/ 6745 365.html (January 8, 2008).

[15] Hu, J. Y. (2009). <Social Insurance Law $>$ and the Overall Planning of Endowment Insurance. Legal Daily. [Online] Available: http://finance.people.com.cn/insurance/GB/ 136878 /146668/8820781.html (February 11, 2009).

[16] Tao, Z. Y. (2008). On the Cross-regional Transfer and Renewing of Migrant Workers' Endowment Insurance. Journal of Tianjin Trade Union Adminstrators' College. 16 (4). 36-39.

[17] Sun, K. (2004). An Analysis of County and Township Public Finance Reform. Research on Development. 1. 6-9.

[18] Chen, Y. (2008). Construction of Social Security and Reform of Fiscal System. Jianghai Journal. 6. 98-102.

[19] Du, F. J., Zhang, Y. T. (2008). Researches in Problems of Fair and Efficiency of System of Social Security of China. Study \& Exploration. 1. 1-22.

[20] Xi, H., Zhai, S. G. (2014). The Path to Achieve More Fair and Sustainable Pension Insurance System. Chinese Public Administration. 3. 11-14.

[21] Sui, D. C., Dong, L., Zhang, S. T. (2014). On the Combination Problems of Urban and Rural Pension Insurance. Social Science of Beijing. 7. 38-43.

[22] He, Y. C. (2009). NPC Delegate Zheng Chenggong: Hope to Achieve Fairness and Full Coverage in Social Security More Quickly. People's Daily Online. [Online] Available: http://society.people.com.cn/GB/168256/168281/168388/1002 8048.html (March 12, 2009).

[23] Guangzhou Daily. (2008) Ice Breaking of Social Security Transfer and Renewing This Year \& the National Overall Planning of Social Security Years or Decades Later. [Online] Available: http://news.xinhuanet.com/fortune/2008-09/03/cont ent_9759661.htm (September 9, 2008).

[24] Xu, Q. (2008). Value Selection of the Rural Migrant Workers' Endowment Insurance and Solutions to the Predicament. Journal of Nanjing University of Technology (Social Science Edition). 7 (3). 48-52.

[25] Yan, Z. X. (2004). Pension Plan Reform in China: Progress, Problems and Countermeasures. Population \& Economics. 1. $51-54$

[26] Yang, B., Ding, J. D. (2015). The Fiscal Responsibility on Pension Insurance System in China: Differences and Reform. Journal of Central University of Finance \& Economics. 2. 10-17. 